\title{
Impact of Agriculture Land Conversion on Growth Center Changes in Majalengka
}

\author{
Albi Paramasatya ${ }^{1}$ and Iwan Rudiarto ${ }^{2}$ \\ \{albialbi87@gmail.com ${ }^{1}$, irudiarto@yahoo.com² \} \\ ${ }^{1}$ Public Works Agency, Majalengka, Indonesia \\ ${ }^{2}$ Diponegoro University, Semarang, Indonesia
}

\begin{abstract}
The government of Indonesia interpreted policy to accelerate regional development through the industrial sector. This policy will have an impact on regional which land conversion cannot be avoided during increased in economy sector. That phenomenon can changes or shifts in growth centers result from such activity. This study aims to analyze the impact of agriculture land conversion to growth centre changes. The location of this study on Majalengka Regency. Thia study assist with overlay analysis methods in Geographical Information System (GIS) and using agricultural land conversion data in 2009-2017, the result of this study is agriculture land conversion impact to changes of regency growth center.
\end{abstract}

Keywords: Agriculture Land Conversion, Growth Center Changes.

\section{Introduction}

Development in Indonesia is increasing as the government's policy in the development equity. In the development equity, the uneven public welfare distribution in the district/city has been a concern to policy makers and researchers [1]. The problem in regional development equity is not only the economy efficiency but also a matter of justice. Furthermore, the development should focus on the welfare of the region. Also, each country needs to boost local economic development and supporting infrastructure. This is due to the naturally available factors, namely abundant resources, existing infrastructure and/or space formed structural differences can lead to different results [2].

The government of Indonesia Republic interpreted policy to accelerate regional development through the industrial sector. Feasibility of the industrial sector is also supported by the data that the industrial sector was the highest investment in 2017 with a value of US \$ 42.6 billion, with employment up to the end of 2017 reached 17.5 million people [3].

This policy will have an impact on the designated area where it will turn into a competition between the existing tenants and new entrants in the region. The competition is influenced land use industry as a driver of economic development [4]. Therefore, how the industrial structure to adjust the structure of space and correlate the relationship between industrial estates and other land becomes a key issue that must be resolved [5]. This issue is in line with the fact that the development policy affects the structure and spatial patterns as the conversion of agricultural land, traffic congestion, and growth centre changes [6]. Besides, the conversion is a phenomenon that cannot be avoided during waking economy and population grows in a region [7]. The problems mentioned above may cause the possibility of 
shift or change the growth centers. Changes in growth centers need to be included in development plans as a regional development strategy [8].

In previous studies, in order to make strategic decisions in the region development, it is important to identify the determinants that promote or restrain the region [9]. One of the dominant factors that are described in the study is that the existence of industrial areas significantly impacted the growth centers. Moreover, in another study, the spatial pattern of industrial areas can be illustrated by the location, function, frequency, spatial hierarchy and the distance [10]. The concept was to understand the spatial pattern representative of an industrial area in the geographical space. This is to assess for changes or shifts in growth centers result from such activity.

From the explanation above, this study aims to assess the impact of agricultural land conversion to changes in regency growth centers. The output of this study is expected to present how big their impact on growth centers. This study is expected to be an academic study to assess the development policy of the regency.

\section{Data and Methods}

\subsection{Study Location}

This study located in Majalengka Regency and based on the determination Majalengka Regency as an industrial region by the direction of the economic activities development in the east with the movement orientation on Cirebon [11]. This policy is also supported by Spatial Plan Majalengka Year 2011-2031 [12], namely the designation of the largely industrial area covering an area of 1.324 hectares (one thousand three hundred twenty-four) hectares.

Majalengka located in the eastern part of West Java Province. The total area of this district is $1204,24 \mathrm{~km}^{2}$ or 120.424 hectares and divided into 26 sub-districts. Majalengka administratively bordered to Indramayu Regency in the north, Ciamis and Tasikmalaya Regency in the south, Cirebon and Kuningan regency in the east, and the Sumedang Regency in the western part. One of the problems in this area is the increase in industrial area [13], as well as the required recalculation area of each zone because of the current agricultural use, has been allocated to other land uses (land conversion).

\subsection{Data Needs}

This study required some data related to land use. The mapping resource is from Quickbird satellite imagery recorded in 2017. The data needs for this study, as described in Table 1.

Table 1. Data Needs

\begin{tabular}{|c|l|l|l|l|l|}
\hline No & \multicolumn{1}{|c|}{ Data } & \multicolumn{1}{c|}{ Source } & Year & Data Types & \multicolumn{1}{c|}{ Output } \\
\hline 1. & $\begin{array}{l}\text { Land use maps in 2017 } \\
\text { and the conversion of the } \\
\text { land use 2009 to 2017 }\end{array}$ & $\begin{array}{l}\text { Planning Agency that } \\
\text { have been processed } \\
\text { by the author }\end{array}$ & 2017 & Secondary & $\begin{array}{l}\text { Map Centre Changes } \\
\text { in 2017 }\end{array}$ \\
\hline
\end{tabular}

\subsection{Methods}

As in assessing changes in growth centers, the authors used the method of Landscape Expansion Index (LEI) [14]. This index can be classified by specific types to measure growth centre changes. The method used a calculation formula, as described in equation (1): 
$\mathrm{LEI}=100 \times \frac{A o}{A o+A v}$

LEI : Landscape Expansion Index;

Ao : The area of land use change; and

Av : The area of land use expanded at the end of the year/year - y;

Overview of the study area is shown in Figure 1.

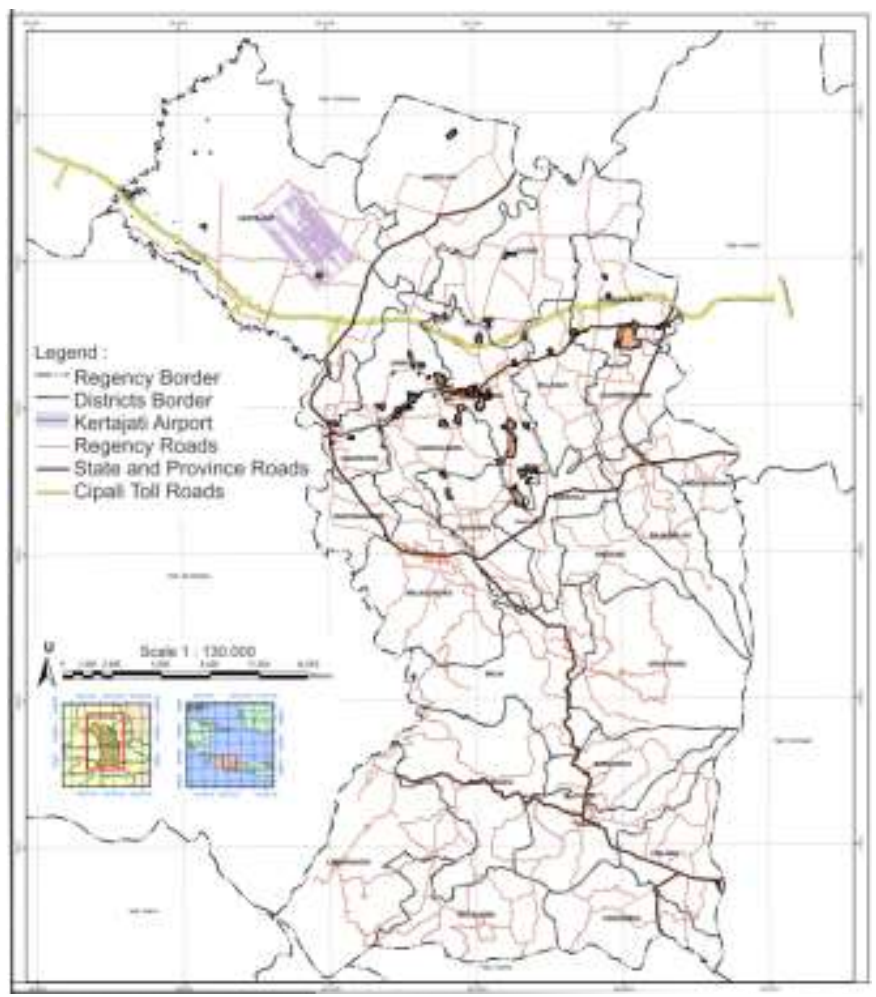

Figure 1. Location of Study

\section{Results and Discussion}

Based on previous studies [15], the development of industrial areas can accelerate the conversion of agricultural land. The developments of these zones not only attract industrial investment but also encourage people to migrate and seek new employment opportunities. This study describes the analyzed how impact of the conversion of agricultural to growth center changes. Total area of land use in 2009 and 2017 described in Table 2.

Table 2. Land use in Majalengka Year 2009 - 2017

\begin{tabular}{|c|c|c|c|c|c|c|}
\hline \multirow{2}{*}{ No. } & \multirow{2}{*}{ Land Use } & \multicolumn{4}{|c|}{ Total Area (HA) } & $\begin{array}{c}\text { Differences } \\
\text { between Year } \\
\text { 2009 \& Year 2017 }\end{array}$ \\
\cline { 3 - 6 } & & Year 2009 & Percentage & Year 2017 & Percentage & $+2,61 \%$ \\
\hline 1 & Forest & $6.688,02$ & $5,00 \%$ & $10.172,45$ & $7,61 \%$ & \\
\hline
\end{tabular}




\begin{tabular}{|c|l|c|c|c|c|c|}
\cline { 5 - 6 } 2 & Farm & $42.166,87$ & $31,54 \%$ & $30.961,14$ & $23,16 \%$ & $-8,38 \%$ \\
\hline 3 & Seasonal farm & $17.843,15$ & $13,34 \%$ & $14.332,02$ & $10,72 \%$ & $-2,62 \%$ \\
\hline 4 & Paddy field & $53.129,60$ & $39,73 \%$ & $50.536,81$ & $37,80 \%$ & $-1,93 \%$ \\
\hline 5 & Open field & $1.928,12$ & $1,44 \%$ & $2.455,32$ & $1,84 \%$ & $+0,40 \%$ \\
\hline 6 & Settlement & $11.683,71$ & $8,74 \%$ & $23.731,53$ & $17,75 \%$ & $+9,01 \%$ \\
\hline 7 & Industry & 0,00 & $0,00 \%$ & 970,42 & $0,73 \%$ & $+0,73 \%$ \\
\hline 8 & $\begin{array}{l}\text { Lake / Situ / } \\
\text { Swamp }\end{array}$ & 272,55 & $0,20 \%$ & 226,42 & $0,17 \%$ & $-0,03 \%$ \\
\hline 9 & Transportation & 0,00 & $0,00 \%$ & 325,92 & $0,24 \%$ & $+0,24 \%$ \\
\hline & Total & $133.712,01$ & $133.712,01$ & $100 \%$ & $133.712,01$ & \\
\hline
\end{tabular}

Based on the information in table 2, the paddy field was dominating land use in 2009 2017. In 2009, the total area of paddy field was 53129.60 hectares. While in 2017, the use of paddy field has an area of 50536.81 hectares. In the span of the period, the paddy field area has decreased by $1.93 \%$, or an area 2597,79 hectares. Also, the farm and seasonal farm has decreased. Until 2017, the farm area has decreased by $8.38 \%$ or 11205.73 hectares. Meanwhile, the seasonal farm area has decreased by $2.62 \%$ or 3511.13 hectares. Conversion of agricultural land is in line with the assessment in previous studies [16], most of the land conversion came from the policies that set on the different administrations unit (local, regional or national), so that policy makers are faced with the pressure to assess the impact of the land use policy.In addition, there are three aspects related to the conversion of land use include: individuals behavior and communities in land use, connectivity and the period of land use [17].

In the next analysis, the conversion of land use data in 2009 - 2017 overlaid with land use maps in 2017. This phase is to assess the Landscape Expansion Index (LEI). These indicators are used to assess how much change the growth centers. Furthermore, the growth center is divided into three types: infilling, edge-expansion, and Outlying [18]. The infilling type refers to one of the openings (or holes) in the old center filled by the new center-growing area expanded more than 50\% (LEI> 50). Edge-expansion type is defined as the center of the new growth or spreads along the strip parallel to the edge with an expanded area of less than $50 \%$ (LEI <50). If the center of the new growth is found isolated from the old, then it is defined as the outlying type. LEI assessment result described in Table 3.

Table 3. Value of LEI (Landscape Expansion Index) Year 2009-2017

\begin{tabular}{|c|l|c|c|c|}
\hline No. & \multicolumn{1}{|c|}{ Land Use } & $\begin{array}{c}\text { Size of Land } \\
\text { Conversion (Ao) }\end{array}$ & $\begin{array}{c}\text { Size of land use } \\
\text { expanded in the final } \\
\text { year (Av) }\end{array}$ & $\begin{array}{c}\text { LEI (Ao / } \\
\text { (Ao + Av)) }\end{array}$ \\
\hline 1 & Paddy field->Open land & 597.83 & 592.64 & 50.22 \\
\hline 2 & Paddy field-> Transportation & 326.51 & 325.92 & 50.05 \\
\hline 3 & Farm-> Open Land & 426.02 & 592.64 & 41.82 \\
\hline 4 & Paddy field-> Industry & 303.50 & 970.42 & 23.82 \\
\hline 5 & Paddy field-> Settlement & 6812.69 & 23731.53 & 22.30 \\
\hline 6 & Settlement -> Industry & 235.67 & 970.42 & 19.54 \\
\hline 7 & Farm ->Paddy field & 10792.55 & 50536.81 & 17.60 \\
\hline 8 & Farm -> Settlement & 4438.42 & 23731.53 & 15.76 \\
\hline 9 & Farm -> Transportation & 47.55 & 325.92 & 12.73 \\
\hline 10 & Seasonal farm ->Paddy field & 5781.03 & 50536.81 & 10.27 \\
\hline 11 & Seasonal farm -> Open Land & 57.91 & 592.64 & 8.90 \\
\hline 12 & Seasonal farm-> Industry & 64.36 & 970.42 & 6.22 \\
\hline 13 & Forests -> Transportation & 19,20 & 325.92 & 5.56 \\
\hline
\end{tabular}




\begin{tabular}{|c|l|c|c|c|}
\hline No. & \multicolumn{1}{|c|}{ Land Use } & $\begin{array}{c}\text { Size of Land } \\
\text { Conversion (Ao) }\end{array}$ & $\begin{array}{c}\text { Size of land use } \\
\text { expanded in the final } \\
\text { year (Av) }\end{array}$ & $\begin{array}{c}\text { LEI (Ao / } \\
\text { (Ao + Av)) }\end{array}$ \\
\hline 14 & Open Land -> Transportation & 18.55 & 325.92 & 5.39 \\
\hline 15 & Seasonal farm -> Settlement & 1321.57 & 23731.53 & 5.28 \\
\hline 16 & Open Land -> Industry & 38,39 & 970.42 & 3.81 \\
\hline 17 & Forests -> Open Land & 22.26 & 592.64 & 3.62 \\
\hline 18 & Forests ->Paddy field & 1352.39 & 50536.81 & 2.61 \\
\hline 19 & Farm -> Lake / Situ / Swamp & 5.62 & 226.42 & 2.42 \\
\hline 20 & Farm -> Industry & 16.28 & 970.42 & 1.65 \\
\hline
\end{tabular}

Table 3 describes that the use of paddy field, farm and seasonal farm were the most converted lands to other land uses. The highest LEI index values are on paddy field into open land, paddy field into transportation and farm into open land. The highest index value reached 50.22 on the use of paddy field into open land. This can be interpreted by 50.22 percent of the total paddy land use has changed. The distribution of LEI index values as described in Figure 2.

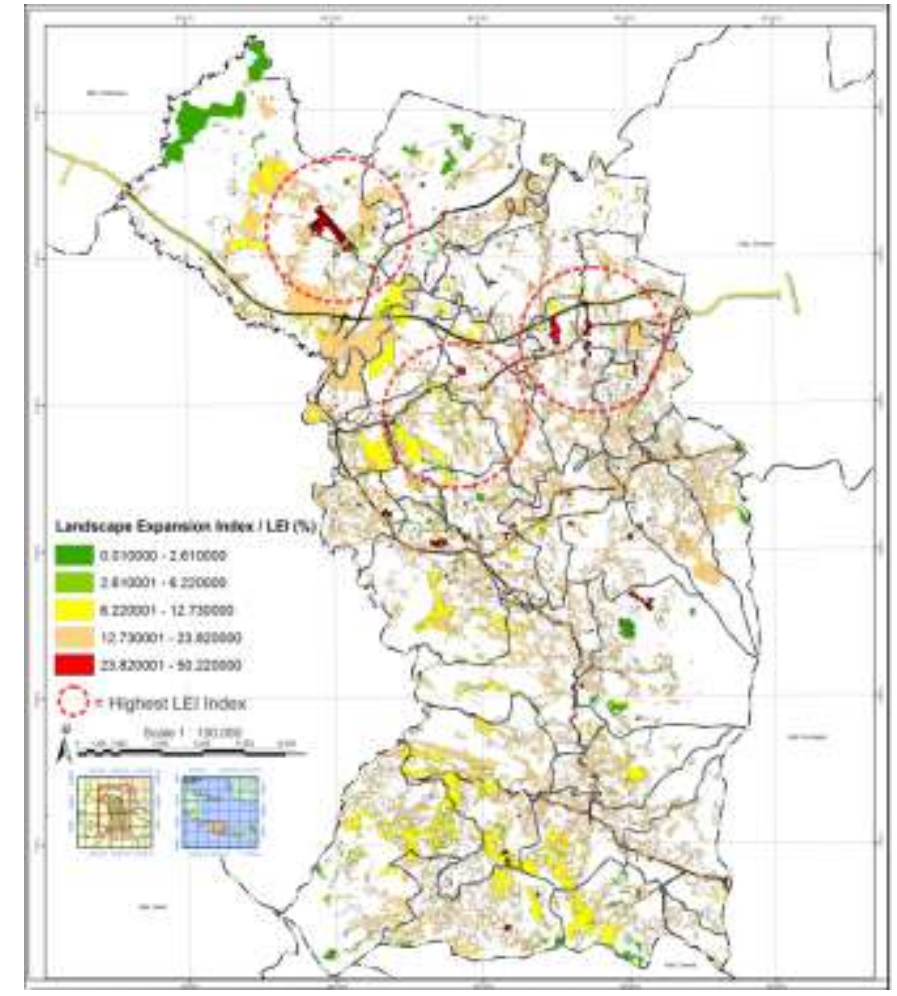

Figure 2. Value of Expansion Landscape Index (LEI) Year 2009-2017

Based on Figure 2, it can be explained that the highest LEI index values are in the northern region of the district. It shows that land expansion in the area is quite large. This phenomenon caused by Land Conversion, which causes land expansion. In some previous literature, studies have discussed this matter. The spatial element plays an important role in 
supporting regional development [19]. In another study, the differentiating factor for regional development of each region includes investments that represent economic resources; population growth; human resources; infrastructure; trade openness; government spending; financial institutions and economic structures [20]. In this study, agricultural land conversion started with government policy in one region. These conversions trigger major shifts in growth centers. The changes of growth center, as illustrated in Figure 3.

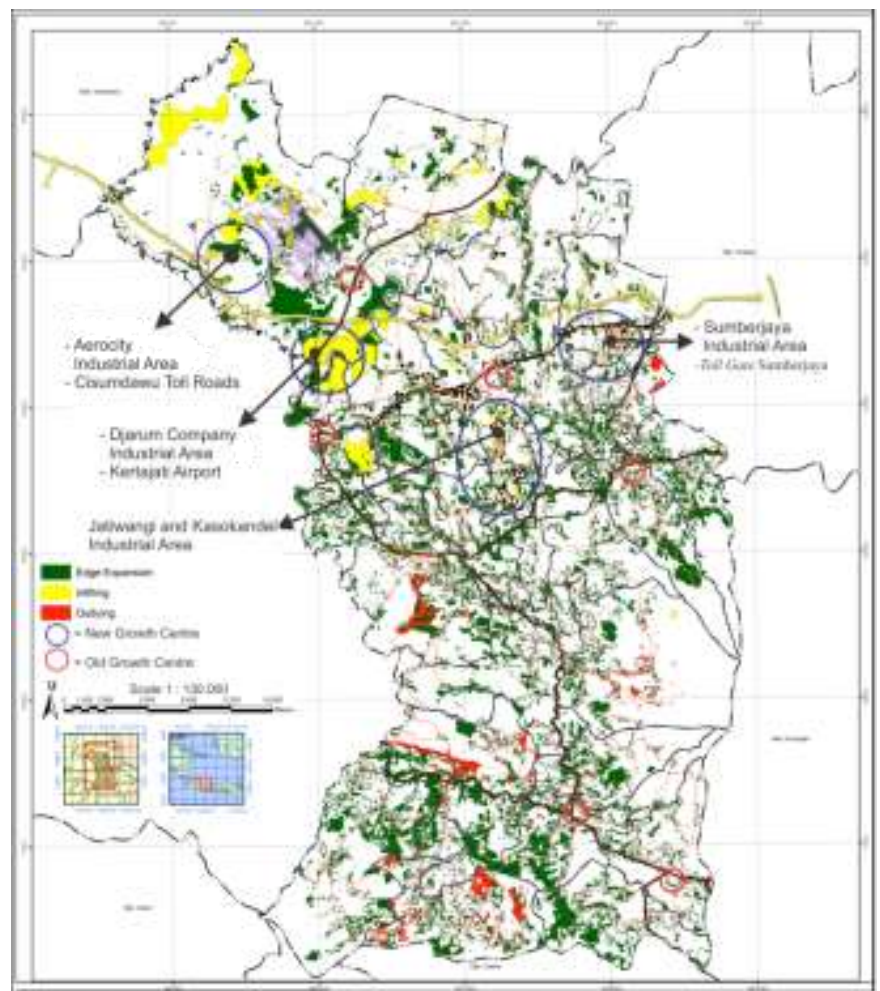

Figure 3. Growth Centre Changes Year 2017

Figure 3 shows that there is a shift in the growth center to the northern area of the district. In 2009, a growth center spread evenly in the center and south of the district. While in 2017, the center of growth shifted to the northern part of the district. This phenomenon explained that new activities such as the manufacturing industry affect other activities that already exist [21]. These activities attract new comers from other regions and affect the patterns of land use change from rural to urban areas. Furthermore, land use must be used to describe space structures [22]. Using land use data, the experts can describe the regularities and irregularities in space structure. The space structure divided into two types; first, relative activity is centralized or decentralized depending on how big the concentration in the nearby central business district. Second, the activities grouped in a polycentric pattern or scattered by a more regular pattern. This growth pattern is the one that creates the growth center.

The Land Conversions, especially agricultural land use, are facing the consequence of government policy. Also, it is in line with the output of the previous studies that accessibility, interaction and spatial policy area is an important factor in determining the Land Conversion 
[23]. The changes in land use are going along with regional development. It is proved by the phenomenon occurring in developing countries caused by those conversions [24]. Another study explains that the land conversion from the natural state into cultivated areas is a permanent effect [25] and mostly unable to be restored by human interaction with the environment. This affects the environment, both physical and spatial.

The change of the growth center is caused by the decision in location choosing which more affected by the accessibility than the availability of facilities, recreation areas and public spaces [26]. This fact indirectly indicates the change of use of agricultural land into other land uses. Geographically, a growth center [27] is a location that has a lot of facilities and services so that it becomes the center of attraction (pole of attraction). From that definition, the growth center is an attraction for residents to move in to the area. The policy of industrial areas development cause high number of agricultural land conversion.

\section{Conclusion}

Based on the analysis results, until 2017, the paddy field in Majalengka has decreased by $1.93 \%$, or an area 2597,79 hectares. The farm has decreased by $8.38 \%$ or 11205.73 hectares, and the seasonal farm has decreased by $2.62 \%$ or 3511.13 hectares. These areas are converted into residential areas and industry. The converted land result is also supported by the high number of the LEI index, reaching 50.22 in the northern region of the district. It proves that the land converted number in the region is high.

From this study, it can be concluded that the conversion of agricultural land use changes affects the growth centers in Majalengka. The impact of the land conversion is the shift of the growth centers from the central to the southern and northern part of the district. It is because the northern region of the district is designated as the industrial development areas. The development is also supported by access to the airport and highway transport. Important findings on this study is decreased of agricultural land especially on farm an seasonal farm can affect growth centre changes on region. Because agricultural land which converted to another land use can impact surrounding area of regional growth centre. The impact can be form to many facilities builds and accelerate regional economy in that area. And also it can affect Changes in growth centers have consequences for the improvement of infrastructure needs and the impact in the environment of the surrounding areas.

\section{Acknowledgments}

This article is part of a thesis entitled "Implication Of Industrial Growth Centre Determination on Regional Development In Majalengka Regency" funded by the Ministry of Public Works and Housing.

\section{References}

[1] Capello, R., and Nijkamp, P. (Eds.) .: Handbook of regional growth and development theories. Vol. 1, pp. 1-16. Edward Elgar Publishing, UK (2009).

[2] Yao, S .: Walrasian equilibrium computation, network formation, and the Wen theorem. Review of Development Economics.vol. 6 (3).pp. 415-427 (2002).

[3] The Ministry of Industry of the Republic of Indonesia .: Master Plan Industrial Estate in Majalengka. Directorate General for Development zoning Industry Ministry of Industry of the Republic of Indonesia, Indonesia (2017).

[4] Zhu, J .: The impact of industrial land use policy on industrial change. Land Use Policy. vol. 17 (1), pp. 21-28 (2000). 
[5] Yang, SW, Lv, J., Yang, YJ, Chen, F., \& Liu, GJ: Evolution of Industrial Land Location in Xuzhou City since Chinese Reform and Opening-up. Procedia Engineering. vol. 198, pp. 1137-1148 (2017).

[6] Qiu, R., Xu, W., and Zhang, J .: The transformation of urban industrial land use: a quantitative method. Journal of Urban Management.vol. 4 (1), pp. 40-52 (2015).

[7] Tan R, Beckmann V, Van den Berg L, Qu F .: Governing farmland conversion: Comparing China with the Netherlands and Germany. Land Use Policy. vol. 26, pp. 961-974(2009).

[8] Lo, FC, and Salih, K. (Eds.) .: Growth pole strategy and regional development policy: the Asian experience and alternative approaches. Elsevier (2013).

[9] Lu, C., Wu, Y., Shen, Q., \& Wang, H .: Driving force of urban growth and regional planning: A case study of China's Guangdong Province. Habitat international.Vol. 40, pp. 35-41 (2013).

[10] Yang, Z., Song, T., \& Chahine, T .: Spatial representations and policy implications of industrial coagglomerations, a case study of Beijing. Habitat International.Vol. 55, pp. 32-45 (2016).

[11] West Java Provincial Government.: West Java Provincial Regulation No. 22 Year 2010 on Spatial Plan of West Java province Years 2009-2029 (2010).

[12] Majalengka Regency Government.: West Java Provincial Regulation No. 11 Year 2011 on Spatial Planning Majalengka Year 2011-2031 (2011).

[13] Majalengka Regency Government.: Review of the Spatial Plan Majalengka Year 2011-2031: Planning, Research and Regional Development Majalengka (2017).

[14] Liu, X., Li, X., Chen, Y., Tan, Z., Li, S., \& Ai, B .: A new landscape index for quantifying urban expansion using multi-temporal remotely sensed data. Landscape ecology.Vol. 25 (5), pp. 671-682 (2010).

[15] Azadi, H., Ho, P., \&Hasfiati, L .: Agricultural land conversion drivers: A comparison between less developed, developing and developed countries. Land Degradation \& Development. Vol. 22 (6), pp. 596-604 (2011).

[16] Fragkias, M., \& Seto, KC.: The Urban Land-Use Change, Models, Uncertainty, and policymaking in Rapidly Growing Developing World Cities: Evidence from China. In Land Use Change: Science, Policy, And Management, pp. 139-160. Taylor \& Francis Group, LLC : USA (2008).

[17] Aspinall, R., \& Staiano, M .: A conceptual models for land system dynamics as a coupled human environment system. Land.Vol. 6 (4), pp. 81 (2017).

[18] Shi, Y., Sun, X., Zhu, X., Li, Y., \& Mei, L .: Characterizing growth types and analyzing growth density distribution in response to urban growth patterns in peri-urban areas of Lianyungang City. Landscape and urban planning.Vol. 105 (4), pp. 425-433 (2012).

[19] Hodgkinson, A., Nyland, C., \&Pomfret, S .: The determination of location in New South Wales. Regional Studies.Vol. 35 (1), pp. 39-55 (2001).

[20] Vidyattama, Y .: A search for Indonesia's regional growth determinants. ASEAN Economic Bulletin.Vol. 27 (3), pp. 281-294 (2010).

[21] Pruksanubal, B .: Land use transformation process in Chachoengsao province, Thailand. ProcediaSocial and Behavioral Sciences.Vol. 222, pp. $772-781$ (2016).

[22] Anas, A., Arnott, R., \& Small, KA: Urban spatial structure. Journal of economic literature.Vol. 36 (3), pp. 1426-1464 (1998).

[23] AK Braimoh and T. Onishi .: Spatial determinants of urban land use change in Lagos, Nigeria. Land use policy. Vol. 24, no. 2, pp. 502-515 (2007).

[24] Y. Zhou et al .: The effect of land use planning (2006-2020) on construction land in China's growth. Cities.Vol. 68, no.October 2016, pp. 37-47, (2017).

[25] H. Long, Y. Liu, X. Hou, T. Li, and Y. Li .: Effects of land use transitions due to rapid urbanization on ecosystem services: Implications for urban planning in the new developing area of China. Habitat International. Vol. 44, pp. 536-544 (2014).

[26] Gordon, Peter Richardson, Harry W., \& Yu, Gang .: Metropolitan and non-metropolitan employment trends in the US: Recent evidence and implications. Urban Studies.Vol. 35 (7), pp. 1037- 1057 (1998). 
[27] Gulo, Y .: Identification Centers Supporting Regional Growth And Development In Nias regency. Widyariset.Vol.18 (1), pp.37-48 (2015). 